\title{
Prevalence and factors associated with elementary lesions in hospitalized elderly
}

\author{
Prevalência e fatores associados às lesões elementares em idosos internados
}

Clóris Regina Blanski Grden ${ }^{1}$, Taís Ivastcheschen ${ }^{1}$, Luciane Patrícia Andreani Cabral ${ }^{1}$, Péricles Martim Reche ${ }^{1}$, Danielle Bordin ${ }^{1}$

Objective: to analyze the prevalence and factors associated with elementary lesions in the elderly hospitalized in a teaching hospital. Methods: cross-sectional study with 202 elderly people. A sociodemographic and clinical questionnaire and a nursing physical examination were applied. For analysis, Stata software ${ }^{\circledR}$ version 12 was used. Results: a total of $176(87.1 \%)$ participants had some elementary lesion. Primary elementary lesions presented significant statistical relationship with age range $\geq 80$ years $(p=0.023)$, respiratory diseases $(p=0.029)$, medical devices $(\mathrm{p}=0.000)$, restricted mobility $(\mathrm{p}=0.001)$, independence $(\mathrm{p}=0.006)$, or need for aid $(\mathrm{p}=0.007)$. Secondary elementary lesions were associated with being married $(\mathrm{p}=0.007)$, medical devices $(\mathrm{p}=0.029)$, and restricted mobility $(\mathrm{p}=0.012)$. Conclusion: there was high prevalence of elementary lesions in hospitalized elderly and important associated factors. This highlights the importance of nurses to evaluate, identify, and conduct preventive care specific to this population.

Descriptors: Geriatric Nursing; Wounds and Injuries; Hospitalization; Skin Aging; Risk Factors.

Objetivo: analisar a prevalência e os fatores associados às lesões elementares em idosos internados em hospital de ensino. Métodos: estudo transversal, realizado com 202 idosos internados em hospital de ensino. Aplicou-se questionário sociodemográfico, clínico e exame físico de enfermagem de pele e anexos. Para análise, utilizou-se software Stata versão $12^{\circledR}$. Resultados: constatou-se que $176(87,1 \%)$ participantes apresentavam alguma lesão elementar. Para lesões elementares primárias, identificou-se relação estatística significativa com faixa etária $\geq 80$ anos $(\mathrm{p}=0,023)$, diagnóstico de doenças do aparelho respiratório $(\mathrm{p}=0,029)$, dispositivos médicos $(\mathrm{p}=0,000)$, mobilidade restrita $(p=0,001)$, independente $(p=0,006)$ ou com auxílio $(p=0,007)$. As lesões elementares secundárias mostraram-se associadas a ser casado $(p=0,007)$, dispositivos médicos $(p=0,029)$ e mobilidade restrita $(\mathrm{p}=0,012)$. Conclusão: identificou-se alta prevalência de lesões elementares em idosos internados e importantes fatores associados. Ao ponderar os fatores associados, reconhece-se a importância de a equipe de enfermagem avaliar, identificar e realizar cuidados preventivos específicos a esse grupo populacional.

Descritores: Enfermagem Geriátrica; Ferimentos e Lesões; Hospitalização; Envelhecimento da Pele; Fatores de Risco.

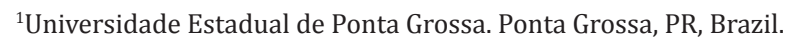

Corresponding author: Clóris Regina Blanski Grden

Rua Teodoro Sampaio, 888 - Oficinas. CEP: 84.036-070. Ponta Grossa, PR, Brazil. E-mail: reginablanski@hotmail.com; crkblanski@uepg.com
} 


\section{Introduction}

The skin is in constant renewal and is the largest and heaviest organ of the human body, consisting of structures divided into epidermis, dermis, and hypodermis. It gives the individual mechanical, microbiological, and physiological protection, regulation of body temperature, reception of stimuli, and production of D vitamin ${ }^{(1)}$.

Intrinsic and extrinsic factors contribute to the aging process of the skin, in which there is progressive loss of structural integrity and physiological function $^{(2)}$. Intrinsic aging occurs inevitably as a natural consequence of physiological changes, since extrinsic factors can be in varying and controllable degrees and include nutrition, invasive devices, mechanical force, humidity, diaper use, and physical mobility ${ }^{(3)}$. However, both intrinsic and extrinsic factors are associated with deterioration of the skin, which can produce elemental lesions, hospitalization, and significant morbidity ${ }^{(4-5)}$. Therefore, the maintenance of skin integrity in hospitalized elderly should be a vital component of nursing $\operatorname{care}^{(1-6)}$.

Elementary lesions are defined as any structural modification of the skin, which have different causes, such as circulatory, hyperplastic, metabolic, inflammatory, and degenerative ${ }^{(7)}$. Lesions are subdivided into primary elementary lesions (color changes, net collections and solid collections) and secondary elementary lesions (changes in texture, thickness, and tissue loss) ${ }^{(8)}$. In practice, scientific literature on skin lesions is vast. However, imprecise terminology for classifications makes the communication between researches difficult ${ }^{(3-4)}$.

When considered an ideal marker of chronological age, the physiological alterations of the skin contribute significantly to the appearance of the lesions in the elderly. In fact, this age range presents at least one skin lesion, but two or more lesions simultaneously are frequent ${ }^{(2)}$, a condition that can affect the autonomy, independence, and self-image of patients.

Advanced age, presence of chronic diseases, restriction of mobility, use of medications, edema, and length of hospitalization are factors associated with skin changes in the elderly ${ }^{(1,3)}$. In this context, there is the need for actions of prevention, identification, and treatment of elemental lesions, especially by the nursing team. To that end, nurses should be able to identify the prevalence and factors associated with elementary lesions in the elderly, making it possible to construct an intervention plan that meets the specificities of patients, such as positioning and change of position, mobility restriction, skin surveillance and monitoring.

In view of the above, the objective was to analyze the prevalence and factors associated with elementary lesions in the elderly hospitalized in a teaching hospital.

\section{Methods}

This is a cross-sectional study carried out with 202 elderly people hospitalized at a teaching hospital in Campos Gerais, Brazil, from September 2017 to March 2018. Participants were included by non-probabilistic consecutive convenience sampling, in which the researchers selected members of the population by availability.

The parameters used to select the sample were: a) age greater than or equal to 60 years; b) having been hospitalized for at least 24 hours in the institution during the period of data collection; and c) having cognitive ability to answer the questions of the study, evaluated through the Mini Mental State Examina$\operatorname{tion}^{(9)}$. In the case of elderly people with no cognitive conditions to answer the research questions, at the interview stage, the caregiver/family member was invited to participate, for which the following inclusion criteria were established: a) being a caregiver/ family member aged over 18 years; b) having lived with the elderly for at least three months, and being the respondent when the elderly presents cognitive $\operatorname{deficit}^{(9-10)}$.

In order to classify and characterize the sample, 
a sociodemographic and clinical questionnaire was applied at the bedside, considering the following variables: gender, age, marital status, education (illiterate, low - one to four incomplete years of study, average four to eight incomplete years of study, high - equal or more than eight years of study), skin color, diagnosis according to the International Classification of Diseases and Related Health Problems, length of stay, chronic illness, smoking, use of medication, use of medical devices, mobility, and body mass index. An instrument was also specifically built to perform the nursing physical examination and included evaluation of the skin and attachments of the various segments, scalp and hair, face skin, turgor, skin temperature, thickness, texture, presence of scars, sensibility, pruritus, nails, palpable pulses, nutrition measures, and primary and secondary elementary lesions. The instrument was built based on references that address the semiology of the skin with adaptation to the elderly patient ${ }^{(4,8,11)}$.

The data collection team consisted of undergraduate scholarship students in nursing and resident nurses of the multiprofessional program for elderly health. In order to train and calibrate the data collection team to be updated on terms and concepts, as well as the identification of lesions, a 45-hour theoretical-practical course was carried out on the evaluation of the elderly's skin, which included the following themes: elementary lesions, pressure lesion, friction lesion, adhesive lesion, incontinence associated with dermatitis, prevention and treatment for pressure lesion. For the patients who presented lesions, care and guidance actions were conducted with the staff, the elderly, and the family.

Data were tabulated and analyzed using Stata ${ }^{\circledR}$ software version 12 (StataCorp LP, CollegeStation, TX, USA). Initially, data were submitted to exploratory and descriptive analysis, then to inferential analysis, and the prevalence and prevalence ratios (PR) were calculated. In studies in which individuals with established clinical condition are prevalent cases, one can only estimate the proportion of individuals with the clinical condition installed or not. In this research, the prevalence ratio was to determine the ratio between individuals with elementary lesions. The prevalence ratios were interpreted as follows: $P R=1$, there is no association between the presence of elementary lesion and factor exposure; PR $>1$, the factor to which the individual is exposed is a risk factor for elementary lesion; and $\mathrm{PR}<1$, the factor to which the individual is exposed is a protective factor for elementary lesion.

To test the differences between proportions, the chi-square test was used, with statistical significance of $\mathrm{p}<0.05$. The Chi-square test assumptions randomness of the data, expected frequencies greater than or equal to 1 and no more than $20.0 \%$ of the expected frequencies below 5 were met. When it was not possible to perform the chi-square test, Fischer's exact test was used.

The project was approved by the Ethics Committee of the State University of Ponta Grossa, according to opinion no 1,461,471 and Certificate of Presentation for Ethical Approval no 66782217,9,0000,5689. The ethical precepts of voluntary and consensual participation of each subject were respected, according to the resolution in force at the time of the research. After the interviewee was informed and signed the said term, the interview was conducted.

\section{Results}

Of the 202 elderly surveyed, there was a predominance of 103 females (51.0\%); age range between 60-69 years, 86 (42.5\%); mean age of 71 years $( \pm 0.61)$; married, 105 (52.0\%); with low schooling (one to four incomplete years of study), 120 (59.4\%); and white, 147 (72.8\%).

Of the participants, 166 (82.2\%) had stayed hospitalized between 1-10 days, with an average time of 7.1 days $( \pm 0.59) ; 170$ (84.3\%) had chronic diseases; 144 (71.3\%) were not smokers; 197 (97.5\%) used medication; 150 (74.3\%) used medical devices; $76(37.6 \%)$ were independent for mobility; and 78 (38.6\%) had eutrophic body mass index.

It was found that $176(87.1 \%)$ participants had 
some elementary lesion, 152 (75.3\%) had primary elementary lesions, and 151 (74.7\%) had secondary elementary lesions. A total of 364 primary lesions were identified, of which 236 (64.8\%) were color changes, 74 (20.4\%) were liquid collections, and 54 (14.8\%) were solid collections. The secondary lesions totaled 324, of which 158 (48.8\%) were changes in texture and thickness, and 166 (51.2\%) were tissue losses.

It was observed that the age group $\geq 80$ years ( $P R=1.27, p=0.023)$, diagnosis of respiratory diseases ( $P R=1.25, p=0.029)$, use of medical devices
$(\mathrm{PR}=1.53, \mathrm{p}=0.000)$, restricted mobility $(\mathrm{PR}=1.78$, $\mathrm{p}=0.001$ ),

being independent $(\mathrm{PR}=1.69, \mathrm{p}=0.006)$, or having need for aid ( $P R=1.77, p=0.007)$ were independent factors and significantly associated with the presence of primary elementary lesions (Table 1).

The independent factors and significantly associated with the presence of secondary elementary lesions were the variables being married $(\mathrm{PR}=1.28$, $\mathrm{p}=0.007)$, use of medical devices ( $\mathrm{PR}=1.23, \mathrm{p}=0.029)$, and restricted mobility $(\mathrm{PR}=1.34, \mathrm{p}=0.012)$ (Table 2).

Table 1 - Prevalence ratios between sociodemographic and clinical characteristics and primary elementary lesions of elderly people admitted to a teaching hospital

\begin{tabular}{|c|c|c|c|c|c|c|}
\hline Variable & $\begin{array}{c}\text { With primary } \\
\text { lesion } \\
\mathbf{n}(\%)\end{array}$ & $\begin{array}{c}\text { Without } \\
\text { primary lesion } \\
\mathbf{n}(\%)\end{array}$ & $\begin{array}{l}\text { Total } \\
\text { n (\%) }\end{array}$ & $\begin{array}{c}\text { Prevalence } \\
\text { Ratio }\end{array}$ & IC95\%* & $\begin{array}{c}\text { p-valor } \\
\text { do } \chi^{2}\end{array}$ \\
\hline \multicolumn{7}{|l|}{ Gender } \\
\hline Male & $72(72.7)$ & $27(27.3)$ & $99(100.0)$ & 1.00 & & \\
\hline Female & $80(77.7)$ & $23(22.3)$ & $103(100.0)$ & 1.06 & $0,91-1,25$ & 0,415 \\
\hline \multicolumn{7}{|l|}{ Age range (years) } \\
\hline $60-69$ & $59(68.6)$ & $27(31.4)$ & $86(100.0)$ & 1.00 & & \\
\hline $70-79$ & $58(76.3)$ & $18(23.7)$ & $76(100.0)$ & 1.11 & $0,91-1,34$ & 0,274 \\
\hline$\geq 80$ & $35(87.5)$ & $5(12.5)$ & $40(100.0)$ & 1.27 & $1,06-1,53$ & 0,023 \\
\hline \multicolumn{7}{|l|}{ Marital status } \\
\hline Married & $74(70.5)$ & $31(29.5)$ & $105(100.0)$ & 1.00 & & \\
\hline Single & $18(75)$ & $6(25)$ & $24(100.0)$ & 1.06 & $0,81-1,38$ & 0,658 \\
\hline Widowed & $60(82.2)$ & $13(17.8)$ & $73(100.0)$ & 1.16 & $0,99-1,37$ & 0,074 \\
\hline \multicolumn{7}{|l|}{ Schooling } \\
\hline Average & $21(70.0)$ & $9(30.0)$ & $30(100.0)$ & 1.00 & & \\
\hline Low & $90(75.0)$ & $30(25.0)$ & $120(100.0)$ & 1.07 & $0,82-1,38$ & 0,576 \\
\hline Illiterate & $26(81.3)$ & $6(18.7)$ & $32(100.0)$ & 1.16 & $0,87-1,54$ & 0,301 \\
\hline High & $15(75.0)$ & $5(25.0)$ & $20(100.0)$ & 1.07 & $0,75-1,51$ & 0,699 \\
\hline \multicolumn{7}{|l|}{ Skin color } \\
\hline Black & $13(68.4)$ & $6(31.6)$ & $19(100.0)$ & 1.00 & & \\
\hline White & $113(76.9)$ & $34(23.1)$ & $147(100.0)$ & 1.12 & $0,81-1,54$ & 0,417 \\
\hline Brown & $26(72.2)$ & $10(27.8)$ & $36(100.0)$ & 1.05 & $0,73-1,52$ & 0,767 \\
\hline \multicolumn{7}{|l|}{ Diseases } \\
\hline Others & $52(72.2)$ & $20(27.8)$ & $72(100.0)$ & 1.00 & & \\
\hline Circulatory & $35(79.5)$ & $9(20.5)$ & $44(100.0)$ & 1.10 & $0,89-1,35$ & 0,376 \\
\hline Respiratory & $29(90.6)$ & $3(9.4)$ & $32(100.0)$ & 1.25 & $1,14-1,51$ & 0,029 \\
\hline Digestive & $21(80.8)$ & $5(19.2)$ & $26(100.0)$ & 1.11 & $0,88-1,41$ & 0,391 \\
\hline Osteomuscular/connective tissue & $15(53.6)$ & $13(46.4)$ & $28(100.0)$ & 0.74 & $0,51-1,07$ & 0,074 \\
\hline \multicolumn{7}{|l|}{ Chronic disease } \\
\hline No & $21(65.6)$ & $11(34.4)$ & $32(100.0)$ & 1.00 & & \\
\hline Yes & $131(77.1)$ & $39(22.9)$ & $170(100.0)$ & 1.17 & $0,90-1,52$ & 0,169 \\
\hline \multicolumn{7}{|l|}{ Smoking } \\
\hline Yes & $106(73.6)$ & $38(26.4)$ & $144(100.0)$ & 1.00 & & \\
\hline No & $46(79.3)$ & $12(20.7)$ & $58(100.0)$ & 1.07 & $0,91-1,26$ & 0,395 \\
\hline \multicolumn{7}{|l|}{ Use of medication } \\
\hline No & $148(75.1)$ & $49(24.9)$ & $197(100.0)$ & 1.00 & & \\
\hline Yes & $4(80.0)$ & $1(20.0)$ & $5(100.0)$ & 1.06 & $0,68-1,66$ & 0,638 \\
\hline \multicolumn{7}{|l|}{ Medical Devices } \\
\hline No & $28(53.9)$ & $24(46.1)$ & $52(100.0)$ & 1.00 & & \\
\hline Yes & $124(82.7)$ & $26(17.3)$ & $150(100.0)$ & 1.53 & $1,18-1,99$ & 0,000 \\
\hline \multicolumn{7}{|l|}{ Mobility } \\
\hline Use of technologies & $9(45.0)$ & $11(55.0)$ & $20(100.0)$ & 1.00 & & \\
\hline Restricted & $57(80.3)$ & $14(19.7)$ & $71(100.0)$ & 1.78 & $1,08-2,93$ & 0,001 \\
\hline Independent & $58(76.3)$ & $18(23.7)$ & $76(100.0)$ & 1.69 & $1,02-2,79$ & 0,006 \\
\hline Aid & $28(80.0)$ & $7(20.0)$ & $35(100.0)$ & 1.77 & $1,06-2,96$ & 0,007 \\
\hline
\end{tabular}


Table 2 - Prevalence ratios between sociodemographic and clinical characteristics and secondary elementary lesions of elderly people admitted to a teaching hospital

\begin{tabular}{|c|c|c|c|c|c|c|}
\hline \multirow[t]{2}{*}{ Variable } & $\begin{array}{c}\text { With secondary } \\
\text { lesion }\end{array}$ & $\begin{array}{c}\text { Without } \\
\text { secondary lesion }\end{array}$ & Total & \multirow{2}{*}{$\begin{array}{l}\text { Prevalence } \\
\text { Ratio }\end{array}$} & \multirow[t]{2}{*}{$95 \% \mathrm{CI}^{*}$} & \multirow[t]{2}{*}{$\begin{array}{l}p \text {-value } \\
\text { of } \chi^{2}\end{array}$} \\
\hline & n (\%) & n (\%) & n (\%) & & & \\
\hline \multicolumn{7}{|l|}{ Gender } \\
\hline Male & $74(74.7)$ & $25(25.3)$ & $99(100.0)$ & 1.00 & & \\
\hline Female & $77(74.7)$ & $26(25.3)$ & $103(100.0)$ & 1.00 & $0.85-1.17$ & 0.998 \\
\hline \multicolumn{7}{|l|}{ Age range (years) } \\
\hline $60-69$ & $63(73.3)$ & $23(26.7)$ & $86(100.0)$ & 1.00 & & \\
\hline $70-79$ & $58(76.3)$ & $18(23.7)$ & $76(100.0)$ & 1.04 & $0.82-1.27$ & 0.654 \\
\hline$\geq 80$ & $30(75.0)$ & $10(25.0)$ & $40(100.0)$ & 1.02 & $0.82-1.27$ & 0.835 \\
\hline \multicolumn{7}{|l|}{ Marital status } \\
\hline Widowed & $46(63.1)$ & $27(36.9)$ & $73(100.0)$ & 1.00 & & \\
\hline Married & $85(80.9)$ & $20(19.1)$ & $105(100.0)$ & 1.28 & $1.05-1.56$ & 0.007 \\
\hline Single & $20(83.3)$ & $4(16.7)$ & $24(100.0)$ & 1.32 & $1.02-1.69$ & 0.051 \\
\hline \multicolumn{7}{|l|}{ Schooling } \\
\hline High & $12(60.0)$ & $8(40.0)$ & $20(100.0)$ & 1.00 & & \\
\hline Illiterate & $25(78.2)$ & $7(21.8)$ & $32(100.0)$ & 1.30 & $0.87-1.94$ & 0.160 \\
\hline Average & $25(83.3)$ & $5(16.7)$ & $30(100.0)$ & 1.38 & $0.93-2.05$ & 0.065 \\
\hline Low & $89(74.2)$ & $31(25.8)$ & $120(100.0)$ & 1.23 & $0.85-1.79$ & 0.190 \\
\hline \multicolumn{7}{|l|}{ Skin color } \\
\hline Brown & $26(72.2)$ & $10(27.8)$ & $36(100.0)$ & 1.00 & & \\
\hline White & $109(74.2)$ & $38(25.8)$ & $14(100.0)$ & 1.02 & $0.82-1.28$ & 0.813 \\
\hline Black & $16(84.2)$ & $3(15.8)$ & $19(100.0)$ & 1.16 & $0.88-1.54$ & 0.258 \\
\hline \multicolumn{7}{|l|}{ Diseases } \\
\hline Circulatory & $33(75.0)$ & $11(25.0)$ & $44(100.0)$ & 1.10 & & \\
\hline Respiratory & $20(62.5)$ & $12(37.5)$ & $32(100.0)$ & 0.83 & $0.60-1.14$ & 0.241 \\
\hline Digestive & $21(80.8)$ & $5(19.2)$ & $26(100.0)$ & 1.07 & $0.83-1.38$ & 0.578 \\
\hline Osteomuscular/connective tissue & $21(75.0)$ & $7(25.0)$ & $28(100.0)$ & 1.00 & $0.76-1.31$ & 1.000 \\
\hline Others & $56(77.8)$ & $16(22.2)$ & $72(100.0)$ & 1.03 & $0.84-1.28$ & 0.731 \\
\hline \multicolumn{7}{|l|}{ Chronic disease } \\
\hline No & $22(68.8)$ & $10(31.2)$ & $32(100.0)$ & 1.00 & & \\
\hline Yes & $129(75.8)$ & $41(24.12)$ & $170(100.0)$ & 1.10 & $0.86-1.41$ & 0.394 \\
\hline \multicolumn{7}{|l|}{ Smoking } \\
\hline Yes & $42(72.4)$ & $16(27.6)$ & $58(100.0)$ & 1.00 & & \\
\hline No & $109(75.7)$ & $35(24.3)$ & $144(100.0)$ & 1.04 & $0.86-1.25$ & 0.627 \\
\hline \multicolumn{7}{|l|}{ Use of medication } \\
\hline No & $3(60.0)$ & $2(40.0)$ & $5(100.0)$ & 1.00 & & \\
\hline Yes & $148(75.1)$ & $49(24.9)$ & $197(100.0)$ & 1.25 & $0.60-2.57$ & 0.372 \\
\hline \multicolumn{7}{|l|}{ Medical Devices } \\
\hline No & $33(63.5)$ & $19(36.5)$ & $52(100.0)$ & 1.00 & & \\
\hline Yes & 118(78.7) & $32(21.3)$ & $150(100.0)$ & 1.23 & $0.99-1.54$ & 0.029 \\
\hline \multicolumn{7}{|l|}{ Mobility } \\
\hline Aid & $22(62.9)$ & 13(37.1) & $35(100.0)$ & 1.00 & & \\
\hline Independent & $55(72.4)$ & $21(27.6)$ & $76(100.0)$ & 1.15 & $0.86-1.53$ & 0.321 \\
\hline Restricted & $60(84.5)$ & $11(15.5)$ & $71(100.0)$ & 1.34 & $1.02-1.76$ & 0.012 \\
\hline Use of technologies & $14(70.0)$ & $6(30.0)$ & $20(100.0)$ & 1.11 & $0.75-1.63$ & 0.592 \\
\hline
\end{tabular}




\section{Discussion}

It should be noted that the sampling of this study is representative of the local community, so that it does not allow generalization of the results to other territories. A limitation is the scarcity of studies on elementary lesions. This fact compromises the comparison of the results evaluated with the national and international literature, which justifies the need to carry out epidemiological studies especially with this population.

The prevalence of elementary lesions in this study was in agreement with an international literature review on the principles of skin care in the elderly, pointing out that the majority of the elderly have at least one skin lesion ${ }^{(2)}$, and it becomes important to scale the real problem that these types of lesions cause to the elderly. The heterogeneity of aging, even in the present sample, indicates that older people with greater impairments inspire greater care.

Among the elementary lesions, which affect the epidermis and dermis, have no relief or consistency, which occur by vasodilation, constriction, or extravasation of red blood cells and by reduction or increase of melanin or deposits of other pigments and substances, there was a predominance of color change. Likewise, there has been a high amount of change in tissue texture, thickness, and loss, which may arise from pathological elimination or destruction and repair in subcutaneous tissues ${ }^{(8)}$.

Regarding the age group, a significant association was found between elderly individuals aged 80 years and older and primary elementary lesions, a fact that may be justified due to changes in skin and in subcutaneous tissue. This change are inherent to aging, as the elderly have a longer exposure time to intrinsic factors and extrinsic or lack of follow-up and care ${ }^{(12)}$. On the other hand, a descriptive and exploratory research carried out with 1,344 elderly in São Paulo found a prevalence of $30.5 \%$ of lesions in the elderly ${ }^{(3)}$. In this study, being married was associated with secondary elementary lesions, however, there were no similar studies to compare the data. This diverges from that found in the literature, that attributes the condition of being married as a positive aspect for the elderly, regarding the aid for prevention and care actions against lesions ${ }^{(4)}$.

The diagnosis of respiratory diseases was significantly associated with primary elementary lesions. A possible justification can be attributed to the repercussions that occur in the skin resulting from systemic reactions that compromise oxygenation, transport of nutrients, and defense cells ${ }^{(13-14)}$. Respiratory diseases sometimes require the elderly to remain in the same position for long periods of time. In addition, the use of medical devices and longer time of hospitalization significantly interfere in the pressure and force exerted on the skin.

Medical devices can cause the breakdown of cutaneous integrity by manipulation and removal, as well as the impact on daily care and position change ${ }^{(15-16)}$. The present study showed a significant association between the use of medical devices and primary and secondary elementary lesions. Although there are no other studies to compare the findings, it is understood that professionals should consider the shorter time of exposure of patients to medical devices, when these are necessary, to stabilize the patients' functions.

Regarding mobility, there was a significant association between restricted, independent mobility and need for aid and primary lesions, as well as a significant association between restricted mobility and secondary elementary lesions. Mobility has a negative impact on the quality and integrity of the skin. Restricted mobility has a greater association because it reduces the self-care capabilities and exposes the subjects to the action of forces such as pressure, friction, and shear ${ }^{(1)}$. In addition, it brings alert on the primary care that these elderly people need against the risk for falls and early mobilization, depending on the condition. 


\section{Conclusion}

The study identified a high prevalence of elementary lesions in hospitalized elderly and important factors associated with primary elementary lesions, especially in the elderly in the age range $\geq 80$ years, with diagnosis of respiratory diseases, use of medical devices, restricted and independent mobility and with need for aid. In addition, a significant association of secondary elementary lesions was found among married elderly, who use medical devices, and with restricted mobility.

\section{Acknowledgements}

To the Conselho Nacional de Desenvolvimento Científico e Tecnológico, process no 115245/2018-9.

\section{Collaborations}

Grden CRB contributed with design, project, interpretation of data, writing of the article, and approval of the final version to be published. Ivastcheschen $\mathrm{T}$ collaborated with project, interpretation of data, and writing of the article. Cabral LPA contributed with design and project. Reche PM assisted in the analysis and interpretation of data. Bordin D participated in the relevant critical review of intellectual content.

\section{References}

1. Todd M. Preventing skin problems in the older population. Nurs Residential Care. 2017; 19(10):5647. doi: doi.org/10.12968/nrec.2017.19.10.564

2. Surber C, Brandt S, Cozzio A, Kottner J. Principles of skin care in the elderly. G Ital Dermatol Venereol [Internet]. 2015 [cited Jan 31, 2019]; 150(6):699716. Available from: https://www.ncbi.nlm.nih. gov/m/pubmed/26349927/

3. Duim E, Sá FHC, Oliveira Duarte YA, Oliveira RCB, Lebrão ML. Prevalence and characteristics of lesions in elderly people living in the community. RevEscEnfermUSP.2015;49(esp):50-6.doi: dx.doi. org/10.1590/S0080-623420150000700008
4. Silva R, Santana RF, Oliveira BG, Carmo TG. High prevalence of skin and wound care of hospitalized elderly in Brazil: a prospective observational study. BMC Res Notes. 2017; 1(1):81. doi: https:// doi.org/10.1186/s13104-017-2410-6

5. Trojahn C, Dobos G, Lichterfels A, Blume-Peytavi U, Kottner J. Characterizing facial skin aging in humans: disentangling extrinsic from intrinsic biological phenomena. Biomed Res Int. 2015; 25. doi: http://dx.doi.org/10.1155/2015/318586

6. Andrada MMC, França M, Alvarez AM, Hammerschmidt KSA. Nursing diagnoses in hospitalized elderly, according to the International Classification of Nursing Practice. Rev Rene. 2015; 16(1):97-105. doi: dx.doi.org/10.15253/21756783.2015000100013

7. Porto CC. Semiologia Médica. Rio de Janeiro: Guanabara e Koogan; 2014.

8. Bolognia JL, Jorizzo JL, Rapini RP. Dermatologia. Rio de Janeiro: Elsevler; 2011.

9. Bertolucci PH, Brucki SM, Campacci SR, Juliano Y. The Mini-mental state examination in a general population: impactofeducational status. Arq Neuro Psiquiatr. 1994; 52(1):1-7. doi: http://dx.doi. org/10.1590/S0004-282X1994000100001

10. Folstein MF, Folstein SE, Mchugh PR. "Minimental state": a practical method for grading the cognitive state of patients for the clinician. J Psychiatr Res. 1975; 12(3):189-98. doi: https:// doi.org/10.1016/0022-3956(75)90026-6

11. Giaretta VMA, Silva AM, Renó ACM, Aguiar DAF, Arantes CMS, Posso MBS. Proposta de escala para avaliar o turgor da pele de idosos. Rev Ciên Saúde [Internet]. 2016 [citado 2019 Fev 01];1(1):1-7. Disponível em: http://revistaeletronicafunvic. org/index.php/c14ffd10/article/view/7/12

12. Matozinhos FP, Velasquez-Melendez G, Tiensoli SD, Moreira AD, Gomes FSL. Factors associated with the incidence of pressure ulcer during hospital stay. Rev Esc Enferm USP. 2017; 51:e03223. doi: dx.doi.org/10.1590/S1980-220x2016015803223

13. Campanili TC, Santos VLCG, Strazzieri-Pulido KC, Thomaz PB, Nogueira PC. Incidence of pressure ulcers in cardiopulmonary intensive care unit patientes. Rev Esc Enferm USP. 2015; 49(spe):7-13. doi: dx.doi.org/10.1590/S0080623420150000700002 
14. Lichterfeld A, Lahmann N, Blume-Peytavi U, Kottner J. Dry skin in nursing care receivers: A multi-centre cross-sectional prevalence study in hospitals and nursing homes. Int J Nurs Stud. 2015; 56:37-44. doi: https://doi.org/10.1016/j. ijnurstu.2016.01.003

15. Chibante CLP, Santo FHE, Santos TD. Profile of clients hospitalized with skin lesions. Rev Enfermería [Internet]. 2015 [cited 2019 Feb 1];31(4). Available from: http://www. revenfermeria.sld.cu/index.php/enf/article/ view/895/136
16. Busanello J, Pinto DM, Schons ES, Baumgart D, Poll MA. Nursing care to adult patient: mucocutaneous injuries prevention and patient safety. Rev Enferm UFSM. 2015; 5(4):597-606. doi: http://dx.doi. org/10.5902/2179769216310 